\title{
The nisin improves broiler chicken growth performance and interacts with salinomycin in terms of gastrointestinal tract microbiota composition
}

\author{
B. Kierończyk', E. Pruszyńska-Oszmałek², S. Świątkiewicz³ , M. Rawski', J. Długosz', \\ R.M. Engberg ${ }^{4}$ and D. Józefiak ${ }^{1,5}$ \\ Poznań University of Life Sciences \\ 'Department of Animal Nutrition and Feed Management, ${ }^{2}$ Department of Animal Physiology and Biochemistry \\ Wołyńska 33, 60-637 Poznań, Poland \\ ${ }^{3}$ National Research Institute of Animal Production, Department of Animal Nutrition and Feed Science, 32-083 Balice, Poland \\ ${ }^{4}$ Aarhus University, Department of Animal Science, 8830 Tiele, Denmark
}

KEY WORDS: bacteriocin, ionophores, performance, microbiota, microecology, broiler

Received: 13 January 2016

Revised: $\quad 8$ July 2016

Accepted: 5 December 2016
${ }^{5}$ Corresponding author:

e-mail:damjo@up.poznan.pl

\begin{abstract}
The aim of present study was to evaluate the potential synergistic effect of salinomycin and nisin on gastrointestinal tract microbial ecology and activity as well as the influence of nisin on broiler chicken growth performance. In the first experiment, which lasted 35 days, such dietary additions as: NA - no additives, SAL - salinomycin (60 mg $\cdot \mathrm{kg}^{-1}$ diet), NIS - nisin (2700 IU $\cdot \mathrm{kg}^{-1}$ diet) were used. Nisin addition in comparison to salinomycin and control treatments, improved body weight gain in the entire experiment (days 1-35) as well as increased feed intake and decreased feed conversion ratio, but only in the starter period (days 1-14). In the second experiment the same dietary additions and also SAL+NIS - salinomycin and nisin $\left(60 \mathrm{mg} \cdot \mathrm{kg}^{-1}\right.$ diet and $2700 \mathrm{IU} \cdot \mathrm{kg}^{-1}$ diet, respectively) were applied. The results of the second experiment indicated that salinomycin and nisin combination decreased the total bacteria counts, as well as Enterobacteriaceae, Clostridium perfringens, Lactobacillus spp./ Enterococcus spp. and Clostridium coccoides-Eubacterium rectale cluster in the ileum. Furthermore, the interaction between applied factors was noticed in the decreasing total bacteria counts, Lactobacillus spp. Enterococcus spp., Clostridium coccoides-Eubacterium rectale cluster and increasing signals from Bifidobacterium spp. as well as Streptococcus sp. Lactococcus. There were no interactions between nisin and salinomycin in terms of organic acids concentration in the crop, gizzard, ileum and caecum, as well as pH value, except gizzard. The results of the present study have indicated the positive effect of nisin on broiler growth performance and the fact that nisin and salinomycin can act synergistically in scope of ileal microbiota ecology modification.
\end{abstract}

\section{Introduction}

In terms of health and growth performance, the modulation of gastrointestinal tract (GIT) microbiota is one of the most important issues of modern broiler chicken nutrition. Wide spectrum of information is available about the influence of probiotics and ionophore coccidiostats on the endogenous chicken microbiota (Engberg et al., 2000; Alloui et al., 2013). However, less is known about bacteriocins, 
which have been used for decades in human foods (Food and Drug Administration, 1988) and may exert important effects on GIT microecology.

Bacteriocins are relatively small peptides produced by bacterial cell ribosomes which have antimicrobial properties against closely related bacteria, other than the producing strain (Józefiak and Sip, 2013). However, only pediocin and nisin are used so far in the production of meat (Janes et al., 2002), vegetables (Vescovo et al., 1995) and milk products (Zottola et al., 1994), which limit food-borne diseases caused by e.g., Listeria monocytogenes or Staphylococcus aureus. Nisin consists of 34 amino acids and is the best known bacteriocin classified as lantibiotics (Class Ia) (Józefiak and Sip, 2013). Its antimicrobial function is directed against Gram-positive bacteria including Clostridium perfringens - one of the causal agents of necrotic enteritis (Riddell and Kong, 1992), and also Gram-negative bacteria (Boziaris and Adams, 1999). In 1983 the European Union designated it as E 234 and in1988 it received the 'Generally Recognized As Safe' (GRAS) status in the USA. However, nisin has not been registered as a feed additive in Europe yet, and its usage in commercial animal nutrition is still not allowed.

Salinomycin, a ionophore coccidiostat, is commonly used against Eimeria spp. in broiler nutrition worldwide. The synergistic effects of this coccidiostat and other substances such as polymyxin B and doxorubicin were observed by Ogita et al. (2009) and Liffers et al. (2013). However, there are limited data concerning the impact of nisin and salinomycin combination on broiler GIT microbial ecology. Previous studies suggested, that salinomycin and nisin exert a similar mode of action in the GIT microbiome and on broiler growth performance (Józefiak et al., 2013). Therefore, the aim of the present study was to investigate the potential synergistic effect of salinomycin and nisin on microbial ecology in broiler chicken GIT as well as influence of nisin on broiler growth performance.

\section{Material and methods}

\section{Preparation of nisin and analysis of nisin concentration}

Nisin was prepared according to the method elaborated at the Department of Biotechnology and Food Microbiology, Poznań University of Life Sciences, using Lactococcus lactis subsp. lactis (ATCC 11454). All details regarding preparation and concentration analyses of nisin have been re- ported previously by Józefiak et al. (2013). In the first experiment only, nisin was encapsulated in a fat matrix as described in detail by Józefiak et al. (2011). The second experiment was carried out without nisin encapsulation, as preliminary data showed that encapsulated nisin does not differ from nonencapsulated nisin in the case of broiler growth performance (unpublished data). The nisin activity expressed in international units (IU) was measured by a spectrophotometer (model Specord 205, Analytik Jena, Jena, Germany), the results were compared with a commercially available nisin standard (1000 IU $\cdot \mathrm{mg}^{-1}$ of solid, Sigma-Aldrich, St. Louis, MO, USA) and converted into IU by equivalent ( $1 \mu \mathrm{g}$ of nisin corresponds to $40 \mathrm{IU})$.

\section{Birds and housing}

All procedures and experiments were conducted accordingly to the guidelines and were approved by the Local Ethics Commission of the Poznan University of Life Sciences (Poznań, Poland) with a respect to animal experimentation and care of examined animals. All efforts were made to minimize the animal suffering.

Two experiments on broiler chickens fed diets differing in nisin and salionomycin supplementation were conducted. The first experiment was carried out to investigate the growth performance of birds fed diet supplemented with nisin or salinomycin. In the second experiment potential synergistic effect of salinomycin and nisin on microecology of the GIT was examined. The housing conditions were the same in both experiments. Birds were kept in floor pens $(1.00 \times 1.00 \mathrm{~m}$ and $1.00 \times 2.5 \mathrm{~m})$ over 35 and 21 days, in the experiment 1 and 2, respectively. Stock density was established on the 10 birds per $\mathrm{m}^{2}$. The lighting cycles (hours of light : hours of dark) were: $23: 1$ during the first week, $19: 5$ from day 7 to 21 , and $23: 1$ from day 22 to 35 . In the first experiment, a total of 420 one-day-old male Ross 308 chicks were randomly distributed to 3 dietary treatments, 14 replicate pens per treatment and 10 birds per pen. In the second experiment, 100 oneday-old female Ross 308 chicks were used. In each treatment 25 birds were defined as individual replicates and the birds were randomly allocated to 4 groups.

\section{Diets and feeding programme}

In both experiments, the birds were fed basal diet (Table 1) with additives ad libitum for 35 or 21 days, in the experiment 1 and 2 , respectively. The diets were prepared in a mash form. The experimental 
Table 1. Composition and nutritive value of basal diet (Experiments 1 and 2)

\begin{tabular}{|c|c|}
\hline Indices & \\
\hline \multicolumn{2}{|l|}{ Ingredients, $\mathrm{g} \cdot \mathrm{kg}^{-1}$} \\
\hline wheat & 566.7 \\
\hline rye & 100.0 \\
\hline soyabean meal & 252.6 \\
\hline beef tallow & 55.8 \\
\hline mineral-vitamin premix ${ }^{1}$ & 3.0 \\
\hline dicalcium phosphate & 11.9 \\
\hline limestone & 5.8 \\
\hline $\mathrm{NaCl}$ & 2.9 \\
\hline $\mathrm{Na}_{2} \mathrm{CO}_{3}$ & 0.2 \\
\hline L-lysine $\mathrm{HCl}$ & 3.4 \\
\hline methionine hydroxy analogue & 2.8 \\
\hline L-threonine & 0.6 \\
\hline \multicolumn{2}{|l|}{ Calculated nutritive value } \\
\hline apparent metabolizable energy, $\mathrm{MJ} \cdot \mathrm{kg}^{-1}$ & 12.97 \\
\hline crude protein, $\mathrm{g} \cdot \mathrm{kg}^{-1}$ & 200.0 \\
\hline
\end{tabular}

${ }^{1}$ provided per kg of diet: IU: vit. A (retinol) 11 166, cholecalciferol 2500 ; mg: vit. E (alpha tocopherol) 80, menadione 2.50, cobalamin 0.02 , folic acid 1.17, choline 379, D-pantothenic acid 12.50, riboflavin 7.0, niacin 41.67 , thiamine 2.17 , D-biotin 0.18 , pyridoxine 4.0 , ethoxyquin 0.09 , Mn 73, Zn 55, Fe 45, Cu 20, I 0.62, Se 0.3

diets were designed to provoke GIT colonization by Clostridium perfringens, due to the use of rye and beef tallow. The treatments applied in the experiment 1: NA - no additives, SAL - salinomycin addition (60 $\mathrm{mg} \cdot \mathrm{kg}^{-1}$ diet), NIS - nisin preparation (2700 IU $\cdot \mathrm{kg}^{-1}$ diet), and in the experiment 2 : NA - no additives, SAL - salinomycin addition (60 $\mathrm{mg} \cdot \mathrm{kg}^{-1}$ diet), NIS - nisin $\left(2700 \mathrm{IU} \cdot \mathrm{kg}^{-1}\right.$ diet) and SAL+NIS - salinomycin $\left(60 \mathrm{mg} \cdot \mathrm{kg}^{-1}\right.$ diet $)$ and $\operatorname{nisin}\left(2700 \mathrm{IU} \cdot \mathrm{kg}^{-1}\right.$ diet $)$.

\section{Data and sample collection}

In the first experiment body weight gain (BWG), feed intake (FI) and feed conversion ratio (FCR) were analysed on day 14 and 35. Moreover, in the second experiment, microbiota populations, $\mathrm{pH}$ and organic acids concentrations in digesta from crop, gizzard, ileum and caecum were determined. At the end of the second experiment (day 21), all chickens were killed by cervical dislocation. The digesta from the crop, gizzard, ileum and caecum were gently squeezed, pooled by segments for 5 birds ( 5 replications per group) and mixed, $\mathrm{pH}$ was measured and about $10 \mathrm{~g}$ was immediately packed, sealed in sterilized plastic bags and stored in $-80{ }^{\circ} \mathrm{C}$ for further organic acids analyses and fluorescent in situ hybridization (FISH) analyses (ileal digesta only).
Table 2. Oligonucleotide probes

\begin{tabular}{|c|c|c|}
\hline Target & Probe & Sequence ( $5^{\prime}$ to $\left.3^{\prime}\right)$ \\
\hline $\begin{array}{l}\text { Bacteroides-Prevotella } \\
\text { cluster }\end{array}$ & Bacto303 & CCAATGTGGGGGACCTT $^{1}$ \\
\hline Clostridium perfringens & Cperf191 & $\begin{array}{l}\text { GTAGTAAGTTG- } \\
\text { GTTTCCTCG }^{1}\end{array}$ \\
\hline Enterobacteriaceae & Enter1432 & CTTTTGCAACCCACT ${ }^{1}$ \\
\hline $\begin{array}{l}\text { Lactobacillus spp./ } \\
\text { Enterococcus spp. }\end{array}$ & Lab158 & GGTATTAGCAYCTGTTTCCA \\
\hline $\begin{array}{l}\text { Clostridium coccoides-Eu } \\
\text { bacterium rectale cluster }\end{array}$ & 1-Erec482 & GCTTCTTAGTCARGTACCG ${ }^{2}$ \\
\hline $\begin{array}{l}\text { Clostridium leptum } \\
\text { subgroup }\end{array}$ & Clept1240 & GTTTTRTCAACGGCAGTC ${ }^{3}$ \\
\hline $\begin{array}{l}\text { Streptococus/ } \\
\text { Lactococcus }\end{array}$ & Strc493 & GTTAGCCGTCCCTTTCTGG ${ }^{4}$ \\
\hline Bifidobacterium spp. & Bif228 & GATAGGGACGCGACCCCAT $^{5}$ \\
\hline
\end{tabular}

\section{Analyses of pH and organic acids}

The $\mathrm{pH}$ value was measured immediately after slaughter using a combined glass and reference electrode (VWR International, pH 1000L, Leuven, Belgium) in pooled digesta from 5 chickens in the crop, gizzard, ileum and caecum. The concentration of organic acids in the contents of the different gastrointestinal segments was determined by gas chromatography (Model 6890, Hewlett Packard, Agilent Technologies, Naerum, Denmark) according to Canibe et al. (2007).

\section{Microbial community analysis by fluorescent in situ hybridization (FISH)}

All details of sample preparation and FISH analyses for bacteria enumeration from ileal digesta were described by Józefiak et al. (2013). The oligonucleotides probes used in this study are presented in Table 2.

\section{Statistical analysis}

The experiments had a completely randomized design, and data was tested using the GLM procedure of SAS software (version 5.0, Iowa, USA). In the first experiment means were separated using a Duncans's one-way ANOVA equation:

$$
\mathrm{Y}_{\mathrm{ij}}=\mu+\alpha_{\mathrm{i}}+\delta_{\mathrm{ij}}
$$

where: $Y_{i j}$ - observed dependent variable, $\mu$ - overall mean, $\alpha_{i}$ - effect of treatment, $\delta_{i j}-$ random error.

In the second experiment two factorial design was applied according to the following general model: 


$$
\mathrm{Y}_{\mathrm{ij}}=\mu+\alpha_{\mathrm{i}}+\beta_{\mathrm{j}}+(\alpha \beta)_{\mathrm{ij}}+\delta_{\mathrm{ij}}
$$

where: $Y_{\mathrm{ij}}$ - observed dependent variable, $\mu$ - overall mean, $\alpha_{i}$ - effect of salinomycin, $\beta_{j}$ - effect of nisin, $(\alpha \beta)_{\mathrm{ij}}$ - interaction between salinomycin and nisin, $\delta_{\mathrm{ij}}$ - random error.

In cases where the overall effect was significant $(P<0.05)$, means were compared pairwise (pdiff). Results are given as the least squares means with pooled standard deviation.

\section{Results}

No mortality was recorded in both experiments. In the first experiment, the supplementation of nisin increased body weight gain (BWG) in the starter period, as compared to SAL and NA diets $(P<0.0001)$ (Table 3$)$. The addition of salinomycin and nisin increased BWG $(P=0.047)$ throughout days $14-35$. In the entire experimental period BWG was significantly higher $(P=0.001)$ in chickens fed diet supplemented with nisin. Significant differences in feed intake (FI) and feed conversion ratio (FCR) between groups were observed only in the first experimental period (days 1-14). Nisin supplementation increased FI $(P=0.001)$ and improved FCR $(P<0.0001)$ in comparison to both SAL and NA diets (Table 3 ).

Table 3. Performance of broiler chickens (Experiment 1)

\begin{tabular}{|c|c|c|c|c|c|}
\hline \multirow{2}{*}{ Indices } & \multicolumn{3}{|c|}{ Treatment $^{1}$} & \multirow{2}{*}{$\begin{array}{l}\text { Polled } \\
\text { SEM }^{2}\end{array}$} & \multirow{2}{*}{$P$-value } \\
\hline & $\overline{N A}$ & SAL & NIS & & \\
\hline \multicolumn{6}{|c|}{ Body weight gain, g } \\
\hline days $1-14$ & $422^{b}$ & $416^{b}$ & $466^{\mathrm{a}}$ & 3.91 & $<.0001$ \\
\hline days $14-35$ & $2075^{b}$ & $2127^{a}$ & $2136^{a}$ & 11.07 & 0.047 \\
\hline days $1-35$ & $2496^{b}$ & $2543^{b}$ & $2601^{\mathrm{a}}$ & 12.36 & 0.001 \\
\hline \multicolumn{6}{|l|}{ Feed intake, $\mathrm{g}$} \\
\hline days $1-14$ & $540^{\mathrm{b}}$ & $537^{\mathrm{b}}$ & $562^{a}$ & 3.17 & 0.001 \\
\hline days $14-35$ & 3194 & 3193 & 3227 & 12.15 & 0.436 \\
\hline days $1-35$ & 3734 & 3729 & 3789 & 13.52 & 0.137 \\
\hline \multicolumn{6}{|c|}{ Feed conversion ratio, $g \cdot g^{-1}$} \\
\hline days $1-14$ & $1.28^{\mathrm{a}}$ & $1.29^{\mathrm{a}}$ & $1.21^{\mathrm{b}}$ & 0.01 & $<.0001$ \\
\hline days $14-35$ & 1.54 & 1.50 & 1.51 & 0.01 & 0.123 \\
\hline days $1-35$ & 1.49 & 1.46 & 1.45 & 0.01 & 0.057 \\
\hline
\end{tabular}

${ }^{1} \mathrm{NA}$ - no additives; SAL - salinomycin (60 $\mathrm{mg} \cdot \mathrm{kg}^{-1}$ diet); NIS - nisin (2700 IU $\left.\cdot \mathrm{kg}^{-1} \mathrm{diet}\right) ;{ }^{2}$ SEM - standard error of mean; ${ }^{\mathrm{ab}}$ - means with different superscripts within a row are significantly different

In the second experiment, the effect of salinomycin decreased $(P<0.0001)$ total bacteria counts, Enterobacteriaceae, Clostridium perfringens, Lactobacillus spp./Enterococcus spp., Clostridium coccoides-Eubacterium rectale cluster, and increased Clostridium leptum subgroup and Bifidobacterium spp. (Table 4). Nisin increased only Bacteroi-
des-Prevotella cluster $(P=0.01)$ and Bifidobacterium spp. counts $(P<0.001)$, whereas the numbers of Clostridium leptum subgroup, Streptococus/ Lactococcus, Clostridium coccoides-Eubacterium rectale cluster were not influenced significantly. Furthermore, the effect of nisin decreased $(P<0.0001)$ total bacteria counts, Enterobacteriaceae $(P=0.05)$, Clostridium perfringens $(P=0.040)$ and Lactobacillus spp./Enterococcus spp. $(P<0.0001)$. The positive interactions between applied factors (SAL+NIS) were noticed in decreasing total number of bacteria $(P<0.0001)$, Lactobacillus spp./Enterococcus spp. $(P=0.015)$, Clostridium coccoides-Eubacterium rectale cluster $(P<0.001)$ and increasing signals from Streptococcus/Lactococcus $(P<.001)$ as well as Bifidobacterium spp. $(P<.0001)$. Simultaneously, the highest concentrations of Streptococcus/Lactococcus $(P=0.0028)$ and Bifidobacterium spp. $(P<0.0001)$ populations were observed in birds from separate SAL and NIS treatments, whereas in NA group the lowest values were detected. In the case of SAL and NIS addition in single way, the positive effect on Bacteroides-Prevotella cluster decrease $(P=0.0003)$ was recorded. Contrary, the use of both additives affected microbiota negatively and enhanced the GIT colonization by BacteroidesPrevotella cluster $(P<0.001)$. There was no interaction between both experimental factors, in scope of population number of Enterobacteriaceae, as well as Clostridium leptum modification.

The effect of salinomycin on $\mathrm{pH}$ value was noticed in case of crop $(P=0.0001)$ and ileum $(P=<.001)$ (Table 5$)$. The salinomycin addition caused $\mathrm{pH}$ increase in above-mentioned segments. The nisin supplementation decreased $\mathrm{pH}$ value in the crop $(P=0.0001)$, as well as caecum $(P=0.002)$. Salinomycin and nisin were not shown to exert a synergistic effect in terms of the digesta $\mathrm{pH}$ values in crop, ileum and caecum. Only in gizzard the interaction between these additives was noticed $(P=0.015)$. The lowest $\mathrm{pH}$ of gizzard digesta was observed in the SAL treatment $(P=0.01)$. There were no significant differences in $\mathrm{pH}$ value among other NA, NIS and SAL+NIS treatments in this segment.

The highest bacterial fermentation activity was observed in crop and caecum (Tables 6 and 7). There were no significant interactions between nisin and salinomycin in case of organic acids concentration in none of GIT segments. The salinomycin addition to the diet decreased concentrations of acetic acid $(P=0.020)$, lactic acid $(P=0.026)$, succinic acid $(P=0.023)$ and total organic acids $(P=0.017)$ in the 
Table 4. Selected microbiota populations (log cfu $\cdot \mathrm{ml}^{-1}$ digesta) in the ileal digesta determined by DAPI staining and fluorescent in situ hybridization (FISH) (Experiment 2)

\begin{tabular}{|c|c|c|c|c|c|c|c|c|c|c|c|c|}
\hline \multirow{3}{*}{ Indices } & \multicolumn{4}{|c|}{ Treatments $^{1}$} & \multirow{3}{*}{$\begin{array}{l}\text { Pooled } \\
\text { SEM }^{2}\end{array}$} & \multicolumn{4}{|c|}{ Main effects } & \multicolumn{3}{|l|}{$P$-value } \\
\hline & \multirow{2}{*}{ NA } & \multirow{2}{*}{ SAL } & \multirow{2}{*}{ NIS } & \multirow{2}{*}{$\mathrm{SAL}+\mathrm{NIS}$} & & \multicolumn{2}{|l|}{ SAL } & \multicolumn{2}{|l|}{ NIS } & \multicolumn{2}{|c|}{ treatments effect } & \multirow{2}{*}{$\frac{\text { interaction }}{\text { SAL x NIS }}$} \\
\hline & & & & & & - & + & - & + & SAL & NIS & \\
\hline$\overline{\mathrm{DAPI}}{ }^{2}$ & $8.50^{\mathrm{b}}$ & $8.60^{\mathrm{a}}$ & $8.48^{b}$ & $8.11^{\circ}$ & 0.004 & $8.49^{a}$ & $8.36^{b}$ & $8.55^{\mathrm{a}}$ & $8.30^{\mathrm{b}}$ & $<.0001$ & $<.0001$ & $<.0001$ \\
\hline Enterobacteriacae & 7.64 & 7.53 & 7.61 & 7.42 & 0.024 & $7.63^{\mathrm{a}}$ & $7.47^{\mathrm{b}}$ & $7.59^{\mathrm{a}}$ & $7.52^{b}$ & $<.0001$ & 0.05 & 0.28 \\
\hline $\begin{array}{l}\text { Bacteroides-Prevotella } \\
\text { cluster }\end{array}$ & $7.63^{b}$ & $7.54^{c}$ & $7.60^{\mathrm{bc}}$ & $7.73^{\mathrm{a}}$ & 0.016 & 7.62 & 7.63 & $7.59^{\mathrm{b}}$ & $7.66^{\mathrm{a}}$ & 0.59 & 0.01 & $<.001$ \\
\hline Clostridium perfringens & 7.90 & 7.55 & 7.78 & 7.53 & 0.021 & $7.84^{\mathrm{a}}$ & $7.54^{\mathrm{b}}$ & $7.73^{\mathrm{a}}$ & $7.66^{\mathrm{b}}$ & $<.0001$ & 0.04 & 0.16 \\
\hline $\begin{array}{l}\text { Lactobacillus spp./ } \\
\text { Enterococcus spp. }\end{array}$ & $8.04^{a}$ & $7.85^{b}$ & $7.86^{\mathrm{b}}$ & $7.53^{c}$ & 0.017 & $7.95^{\mathrm{a}}$ & $7.69^{b}$ & $7.95^{\mathrm{a}}$ & $7.70^{\mathrm{b}}$ & $<.0001$ & $<.0001$ & 0.01 \\
\hline Clostridium leptum & 7.58 & 7.60 & 7.49 & 7.61 & 0.023 & $7.53^{b}$ & $7.61^{\mathrm{a}}$ & 7.59 & 7.55 & 0.04 & 0.29 & 0.17 \\
\hline $\begin{array}{l}\text { Streptococus/ } \\
\text { Lactococcus }\end{array}$ & $7.46^{\mathrm{c}}$ & $7.66^{\mathrm{a}}$ & $7.61^{\mathrm{ab}}$ & $7.55^{\mathrm{bc}}$ & 0.028 & 7.54 & 7.60 & 7.56 & 7.58 & 0.10 & 0.52 & $<.001$ \\
\hline $\begin{array}{l}\text { Clostridium coccoides- } \\
\text { Eubacterium rectale } \\
\text { cluster }\end{array}$ & $7.88^{b}$ & $7.79^{c}$ & $7.98^{\mathrm{a}}$ & $7.58^{\mathrm{d}}$ & 0.020 & $7.93^{\mathrm{a}}$ & $7.69^{b}$ & 7.84 & 7.79 & $<.0001$ & 0.11 & $<.0001$ \\
\hline Bifidobacterium spp. & $7.62^{c}$ & $7.90^{\mathrm{a}}$ & $7.92^{\mathrm{a}}$ & $7.79^{b}$ & 0.015 & $7.77^{\mathrm{b}}$ & $7.84^{\mathrm{a}}$ & $7.76^{b}$ & $7.86^{\mathrm{a}}$ & 0.01 & $<.001$ & $<.0001$ \\
\hline
\end{tabular}

${ }^{1} \mathrm{NA}$ - no additives, SAL - salinomycin (60 $\mathrm{mg} \cdot \mathrm{kg}^{-1}$ diet), NIS - nisin (2700 IU $\cdot \mathrm{kg}^{-1}$ diet), SAL+NIS - mixture of nisin and salinomycin (doses as in SAL and NIS); ${ }^{2} \mathrm{DAPI}$ - total number of bacteria determined by 4',6-diamidino-2-phenylindole staining; ${ }^{3} \mathrm{SEM}$ - standard error of the mean; ${ }^{\mathrm{ab}}$ - means with different superscripts within a row are significantly different for treatments and each main effect separately

Table 5. pH in crop, gizzard, ileum and caecal digesta (Experiment 2)

\begin{tabular}{|c|c|c|c|c|c|c|c|c|c|c|c|c|}
\hline \multirow{3}{*}{ Indices } & \multicolumn{4}{|c|}{ Treatments $^{1}$} & \multirow{3}{*}{$\begin{array}{l}\text { Pooled } \\
\text { SEM }^{2}\end{array}$} & \multicolumn{4}{|c|}{ Main effects } & \multicolumn{3}{|l|}{$P$-value } \\
\hline & \multirow{2}{*}{ NA } & \multirow{2}{*}{ SAL } & \multirow{2}{*}{ NIS } & \multirow{2}{*}{$\mathrm{SAL}+\mathrm{NIS}$} & & \multicolumn{2}{|l|}{ SAL } & \multicolumn{2}{|l|}{ NIS } & \multicolumn{2}{|c|}{ treatments effect } & \multirow{2}{*}{$\frac{\text { interaction }}{\text { SAL } \times \text { NIS }}$} \\
\hline & & & & & & - & + & - & + & $\overline{\mathrm{SAL}}$ & NIS & \\
\hline Crop & 5.71 & 6.29 & 5.13 & 5.84 & 0.159 & $5.42^{\mathrm{b}}$ & $6.05^{\mathrm{a}}$ & $5.98^{a}$ & $5.49^{b}$ & 0.0001 & 0.0001 & 0.57 \\
\hline Gizzard & $3.20^{a}$ & $2.70^{b}$ & $3.08^{\mathrm{a}}$ & $3.13^{a}$ & 0.135 & 3.14 & 2.92 & 2.96 & 3.10 & 0.048 & 0.18 & 0.015 \\
\hline Ileum & 6.48 & 6.87 & 6.58 & 6.82 & 0.086 & $6.53^{b}$ & $6.84^{\mathrm{a}}$ & 6.67 & 6.70 & 0.0008 & 0.72 & 0.37 \\
\hline Caecum & 6.51 & 6.63 & 6.13 & 6.30 & 0.135 & 6.32 & 6.46 & 6.57 & 6.22 & 0.18 & 0.002 & 0.802 \\
\hline
\end{tabular}

${ }^{1}$ see Table $4 ;{ }^{2}$ SEM - standard error of the mean; ${ }^{\text {ab }}$ - means with different superscripts within a row are significantly different for treatments and each main effect separately

Table 6. Organic acids concentrations in crop and gizzard digesta, $\mu \mathrm{mol} \cdot \mathrm{g}^{-1}$ (Experiment 2)

\begin{tabular}{|c|c|c|c|c|c|c|c|c|c|c|c|c|}
\hline \multirow{3}{*}{ Indices } & \multicolumn{4}{|c|}{ Treatments $^{1}$} & \multirow{3}{*}{$\begin{array}{l}\text { Pooled } \\
\text { SEM }^{2}\end{array}$} & \multicolumn{4}{|c|}{ Main effects } & \multicolumn{3}{|c|}{$P$-value } \\
\hline & \multirow{2}{*}{ NA } & \multirow{2}{*}{ SAL } & \multirow{2}{*}{ NIS } & \multirow{2}{*}{ SAL+NIS } & & \multicolumn{2}{|l|}{ SAL } & \multicolumn{2}{|l|}{ NIS } & \multicolumn{2}{|c|}{ treatments effect } & \multirow{2}{*}{$\frac{\text { interaction }}{\text { SAL x NIS }}$} \\
\hline & & & & & & - & + & - & + & SAL & NIS & \\
\hline \multicolumn{13}{|l|}{ Crop } \\
\hline formic acid & $N^{3}$ & 0.71 & 2.06 & 0.74 & 0.34 & 1.03 & 0.73 & 0.30 & 1.40 & 0.547 & 0.103 & 0.131 \\
\hline acetic acid & 6.96 & 4.04 & 16.81 & 8.24 & 1.59 & $11.86^{\mathrm{a}}$ & $6.44^{b}$ & $5.68^{b}$ & $12.52^{\mathrm{a}}$ & 0.020 & 0.009 & 0.220 \\
\hline propionic acid & 0.29 & 0.19 & 0.44 & 0.33 & 0.31 & 0.37 & 0.27 & 0.25 & 0.38 & 0.552 & 0.464 & 0.981 \\
\hline DL-lactic acid & 21.24 & 4.09 & 63.97 & 31.48 & 27.86 & $42.61^{a}$ & $19.74^{b}$ & $13.89^{b}$ & $47.72^{\mathrm{a}}$ & 0.026 & 0.006 & 0.455 \\
\hline succinic acid & 2.89 & 0.50 & 7.39 & 3.03 & 3.36 & $5.14^{\mathrm{a}}$ & $1.94^{\mathrm{b}}$ & $1.86^{b}$ & $5.21^{\mathrm{a}}$ & 0.023 & 0.026 & 0.468 \\
\hline total organic acids & 31.34 & 9.52 & 90.67 & 43.81 & 37.06 & $61.01^{a}$ & $29.12^{b}$ & $21.99^{b}$ & $67.24^{a}$ & 0.017 & 0.005 & 0.339 \\
\hline \multicolumn{13}{|l|}{ Gizzard } \\
\hline acetic acid & 1.98 & 1.93 & 2.83 & 2.33 & 0.63 & 2.58 & 1.96 & 2.44 & 2.16 & 0.069 & 0.365 & 0.386 \\
\hline DL-lactic acid & 1.01 & ND & 3.72 & 1.02 & 1.89 & $2.36^{a}$ & $0.58^{b}$ & $0.58^{b}$ & $2.37^{a}$ & 0.024 & 0.032 & 0.274 \\
\hline total organic acids & 7.62 & 1.94 & 6.05 & 2.99 & 3.56 & $6.84^{\mathrm{a}}$ & $2.54^{\mathrm{b}}$ & 5.18 & 4.52 & 0.020 & 0.686 & 0.423 \\
\hline
\end{tabular}

${ }^{1}$ see Table 4; ${ }^{2}$ SEM - standard error of the mean; ${ }^{3} \mathrm{ND}$ - not detected; ab - within main effects means in a row with different superscripts are significantly different for treatments and each main effect separately; In gizzard digesta in group NA it was also $3.46 \mu \mathrm{mol} \cdot \mathrm{g}^{-1}$ of formic acid, as well as $0.33 \mu \mathrm{mol} \cdot \mathrm{g}^{-1}$ of $\mathrm{n}$-butyric acid was detected 
Table 7. Organic acids concentrations in ileum and caecal digesta, $\mu \mathrm{mol} \cdot \mathrm{g}^{-1}$ (Experiment 2)

\begin{tabular}{|c|c|c|c|c|c|c|c|c|c|c|c|c|}
\hline \multirow{3}{*}{ Indices } & \multicolumn{4}{|c|}{ Treatments $^{1}$} & \multirow{3}{*}{$\begin{array}{l}\text { Pooled } \\
\text { SEM }^{2}\end{array}$} & \multicolumn{4}{|c|}{ Main effects } & \multicolumn{3}{|c|}{$P$-value } \\
\hline & \multirow{2}{*}{ NA } & \multirow{2}{*}{ SAL } & \multirow{2}{*}{ NIS } & \multirow{2}{*}{ SAL+NIS } & & \multicolumn{2}{|c|}{ SAL } & \multicolumn{2}{|l|}{ NIS } & \multicolumn{2}{|c|}{ treatments effect } & \multirow{2}{*}{$\begin{array}{l}\text { interaction } \\
\text { SAL x NIS }\end{array}$} \\
\hline & & & & & & - & + & - & + & $\overline{S A L}$ & NIS & \\
\hline \multicolumn{13}{|l|}{ Ileum } \\
\hline acetic acid & 3.86 & 4.06 & 3.62 & 3.71 & 1.26 & 3.74 & 3.86 & 3.95 & 3.67 & 0.848 & 0.708 & 0.939 \\
\hline DL-lactic acid & 7.67 & 3.65 & 15.45 & 2.81 & 6.98 & $11.56^{\mathrm{a}}$ & $3.17^{b}$ & 5.95 & 9.13 & 0.008 & 0.262 & 0.140 \\
\hline total organic acids & 11.69 & 7.71 & 20.11 & 6.52 & 7.11 & $15.90^{\mathrm{a}}$ & $7.03^{b}$ & 9.99 & 13.31 & 0.004 & 0.221 & 0.089 \\
\hline \multicolumn{13}{|l|}{ Caecum } \\
\hline acetic acid & 60.28 & 67.55 & 72.20 & 61.52 & 10.01 & 66.24 & 64.11 & 63.39 & 66.86 & 0.644 & 0.505 & 0.104 \\
\hline propionic acid & 5.98 & 6.66 & 4.98 & 5.79 & 0.98 & 5.48 & 6.16 & 6.27 & 5.39 & 0.129 & 0.079 & 0.891 \\
\hline iso-butyric acid & 0.38 & 0.48 & 0.40 & 0.31 & 0.17 & 0.39 & 0.38 & 0.42 & 0.36 & 0.980 & 0.543 & 0.349 \\
\hline n-butyric acid & 8.82 & 9.19 & 12.26 & 9.52 & 4.18 & 10.54 & 9.36 & 8.96 & 10.89 & 0.577 & 0.418 & 0.516 \\
\hline n-valeric acid & 0.88 & 1.08 & 0.87 & 0.79 & 0.16 & 0.88 & 0.92 & 0.97 & 0.83 & 0.480 & 0.074 & 0.063 \\
\hline succinic acid & 19.76 & 16.61 & 20.29 & 17.57 & 7.30 & 20.03 & 17.16 & 18.41 & 18.93 & 0.410 & 0.882 & 0.952 \\
\hline total organic acids & 97.99 & 102.82 & 113.03 & 95.50 & 14.5 & 105.51 & 98.64 & 100.06 & 104.27 & 0.351 & 0.580 & 0.160 \\
\hline
\end{tabular}

${ }^{1}$ see Table 4; ${ }^{2}$ SEM - standard error of the mean; ${ }^{3} \mathrm{ND}$ - not detected; ab - within main effects means in a row with different superscripts are significantly different for treatments and each main effect separately; In ileal digesta in group NIS it was also $1.04 \mu \mathrm{mol} \cdot \mathrm{g}^{-1}$ of formic acid, in group NA $0.17 \mu \mathrm{mol} \cdot \mathrm{g}^{-1}$ of propionic acid was detected. In the case of caecal digesta it was also $1.29 \mu \mathrm{mol} \cdot \mathrm{g}^{-1}$ and $0.57 \mu \mathrm{mol} \cdot \mathrm{g}^{-1}$ of formic acid was detected, in group NIS and SAL, respectively. Additionally, in the case of caecal digesta it was also $1.9 \mu \mathrm{mol} \cdot \mathrm{g}^{-1}$ and $1.45 \mu \mathrm{mol} \cdot \mathrm{g}^{-1}$ of DL-lactic acid was detected, in group NA and NIS, respectively.

crop, as well as lactic acid $(P=0.024 ; P=0.020)$ and total organic acids $(P=0.008 ; P=0.004)$ in the gizzard and ileum, respectively. Nisin increased fermentation of acetic acid $(P=0.009)$, lactic acid $(P=0.006)$, succinic acid $(P=0.026)$ and the sum of organic acid $(P=0.005)$ in the crop, as well as lactic acid $(P=0.032)$ in the gizzard. In the case of caecal fermentation, both NIS as well as SAL treatments did not affect short-chain fatty acids composition and simultaneously no interaction between these factors was noticed. Calculations of the percentage concentration of selected organic acids i.e. acetic, butyric and propionic acid, were made (data not shown). There were no significant differences between treatments in all GIT segments. Acetic acid was predominant fermentation product in crop, gizzard and ileum. Its concentration was up to $100 \%$ of the sum of above-mentioned organic acids. In terms of caecal fermentation, the highest value of acetic acid (approx. 80\%) was observed, then $12 \%$ of butyric acid and $8 \%$ of propionic acid.

\section{Discussion}

The current study demonstrated a positive effect of salinomycin and nisin on broiler chicken growth performance and microbiota ecology. The results confirmed that microbiota modulation through ionophore coccidiostats is based on the suppression of Gram-positive pathogens such as Clostridium perfringens (Bjerrum et al., 2005), which causes necrotic enteritis in poultry, and by limiting prolif- eration of Bacteroides, Clostridiacae, Enterobacteriacae and Lactobacillus spp./Enterococcus spp. which can compete with the host-bird for nutrients uptake as well as impair fat absorption through bile acid deconjugation (Masuda, 1981; Klaver and van der Meer, 1993; Czerwiński et al., 2012).

The knowledge about bacteriocin application in livestock nutrition, including poultry, has been limited and has been primarily focused on the preservation properties of these substances in the food industry (Teo and Tan, 2005). Moreover, in many experiments carried out on broiler chickens, where probiotic strains were applied, the potential production of bacteriocins by these microorganisms and their impact on the GIT homeostasis was not investigated as a key factor. Meanwhile, earlier studies conducted on different bacteriocins suggests that divercin AS7 may compensate the negative effects associated with the presence of $C$. perfringens, while nisin supplementation enhanced growth performance of the birds through modulation of GIT microecology (Józefiak et al., 2012, 2013).

Previous studies about bacteriocin application in broiler chicken diets showed nearly equal effects of nisin and salinomycin applied separately (Józefiak et al., 2013). In this work, the possible synergistic influence of these compounds was examined. Hitherto, combinations of different substances with bacteriocins were used for improving their preservation properties and food elongation storage period in food industry by microbiota limitation (Gálvez et al., 2007). The synergistic effects between nisin 
and various substances were repeatedly observed. Combinations of ethanol (Brewer et al., 2002), monolaurin (Mansour et al., 1999), sucrose fatty acid esters - sucrose palmitate and sucrose stearate (Thomas et al., 1998) and reuterin (Arqués et al., 2004) with nisin reduced $L$. monocytogenes, B. licheniformis (vegetative cells and spores), B. cereus (cells and spores), L. plantarum and Staphylococcus aureus development, respectively. Supplementation of these complexes did not exert a negative effect on Gram-negative pathogens. Other studies suggest that combinations of two different bacteriocins could improve their antibacterial activity when compared to those used separately (Bouttefroy and Millière, 2000). However, there are no studies on potential synergistic effects of ionophores and bacteriocins. In the present study combination of salinomycin and nisin influenced GIT microbiota counts. Therefore, it is suggested that those two additives can have more significant antimicrobial activity when used as a mixture. It is well-known that the salinomycin activity is connected with disturbances in osmotic homeostasis in the bacteria cell body (Augustine et al., 1992). On the other hand, the target of nisin is the cytoplasmic membrane which is perforated and then all ions could permeate outside the microbe body (Józefiak and Sip, 2013). Moreover, it is possible that connection of these modes of actions and targets i.e. pathogens may explain the improved antibacterial function. Furthermore, Lactobacilli and Bifidobacterium spp. populations may affect fat absorption by bile salt deconjugation (high bile salt hydrolase activity) (Klaver and van der Meer, 1993). Consequently, their reduction positively improved fat digestibility and utilization in the broiler GIT. In this case, it is very useful to convert these results to practical use, because the synergistic mixture allows to reduce the required dosage of a single compound (Thomas and Isak, 2005).

In the present study the interaction between nisin and salinomycin was noticed only in $\mathrm{pH}$ value of gizzard. Furthermore, nisin supplementation decreased $\mathrm{pH}$ value in crop and caecum. Digesta $\mathrm{pH}$ was lowered in caecum after nisin supplementation, which confirmed the findings of Józefiak et al. (2013). Gálvez et al. (2007) observed, that the lower $\mathrm{pH}$ can enhance bacteriocins efficacy by the translocation of their molecules through the bacterial cell wall. Thus, decreasing of crop $\mathrm{pH}$ value may suggest that this GIT segment is the most important for microbiota suppression in chickens (Kierończyk et al., 2016). Moreover, the $\mathrm{pH}$ values were in agreement with organic acids concentrations which did not differ due to nisin and salinomycin interactions. There were no synergistic effect between experimental factors as well. The microbial fermentation was enhanced in the crop and caecum. However, the highest organic acids concentrations in the crop, gizzard, ileum and caecum in birds fed diet with nisin addition were noticed. In this case, nisin may escalate D-lactic acid synthesis by growth promoting of lactic acid bacteria (LAB) microbiota in comparison to Józefiak et al. (2013). In the case of ileal digesta, the formic acid was detected in the nisin supplemented treatment, which may be the effect of high Bifidobacteria, as well as Clostridia concentration (Macfarlane and Gibson, 1995). Nevertheless, more detailed analyses should be performed to fully describe the microbiota activity.

\section{Conclusions}

The present study suggests that in broiler chicken nutrition, both nisin and salinomycin can act synergistically by modulating microbiota in the GIT. It seems that bacteriocins addition to the broiler diets may be a novel strategy in poultry production, with the aim to control microbial pathogens and improve growth, feed efficiency and animal health.

\section{Acknowledgements}

The current study was supported by the Grant: 'Application of bacteriocin bioactive preparations in broiler chicken nutrition', IMPULS, Foundation for Polish Science.

\section{References}

Alloui M.N., Szczurek W., Świątkiewicz S., 2013. The usefulness of prebiotics and probiotics in modern poultry nutrition: a review. Ann. Anim. Sci. 13, 17-32

Arqués J.L., Fernández J., Gaya P., Nuñez M., Rodrìguez E., Medina M., 2004. Antimicrobial activity of reuterin in combination with nisin against food-borne pathogens. Int. J. Food Microbiol. 95, 225-229, https://doi.org/10.1016/j.ijfoodmicro.2004.03.009

Augustine P.C., Watkins K.L., Danforth H.D., 1992. Effect of monensin on ultrastructure and cellular invasion by the turkey coccidia Eimeria adenoeides and Eimeria meleagrimitis. Poultry Sci. 71, 970-978, https://doi.org/10.3382/ps.0710970

Bjerrum L., Pedersen K., Engberg R.M., 2005. The influence of whole wheat feeding on Salmonella infection and gut flora composition in broilers. Avian Dis. 49, 9-15, https://doi. org/10.1637/7223-061504R

Bouttefroy A., Millière J.-B., 2000. Nisin-curvaticin 13 combinations for avoiding the regrowth of bacteriocin resistant cells of Listeria monocytogenes ATCC 15313. Int. J. Food Microbiol. 62, 65-75, https://doi.org/10.1016/S0168-1605(00)00372-X 
Boziaris I.S., Adams M.R., 1999. Effect of chelators and nisin produced in situ on inhibition and inactivation of Gram negatives. Int. J. Food Microbiol. 53, 105-113, https://doi.org/10.1016/ S0168-1605(99)00139-7

Brewer R., Adams M.R., Park S.F., 2002. Enhanced inactivation of Listeria monocytogenes by nisin in the presence of ethanol. Lett. Appl. Microbiol. 34, 18-21, https://doi.org/10.1046/j.1472765x.2002.01035.x

Canibe N., Højberg O., Badsberg J.H., Jensen B.B., 2007. Effect of feeding fermented liquid feed and fermented grain on gastrointestinal ecology and growth performance in piglets. J. Anim. Sci. 85, 2959-2971, https://doi.org/10.2527/jas.2006-744

Czerwiński J., Højberg O., Smulikowska S., Engberg R.M., Mieczkowska A., 2012. Effects of sodium butyrate and salinomycin upon intestinal microbiota, mucosal morphology and performance of broiler chickens. Arch. Anim. Nutr. 66, 102-116, https://doi.org/10.1080/1745039X.2012.663668

Engberg R.M., Hedemann M.S., Leser T.D., Jensen B.B., 2000. Effect of zinc bacitracin and salinomycin on intestinal microflora and performance of broilers. Poultry Sci. 79, 1311-1319, https:// doi.org/10.1093/ps/79.9.1311

Food and Drug Administration, 1988. Nisin preparation: affirmation of GRAS status as a direct human food ingredient. Fed. Reg. 53, 11247-11251

Franks A.H., Harmsen H.J.M., Raangs G.C., Jansen G.J., Schut F. Welling G.W., 1998. Variations of bacterial populations in human feces measured by fluorescent in situ hybridization with group-specific 16S rRNA-targeted oligonucleotide probes. Appl. Environ. Microbiol. 64, 3336-3345

GálvezA., Abriouel H., López R.L., Omar N.B., 2007. Bacteriocin-based strategies for food biopreservation. Int. J. Food Microbiol. 120, 51-70, https://doi.org/10.1016/j.ijfoodmicro.2007.06.001

Janes M.E., Kooshesh S., Johnson M.G., 2002. Control of Listeria monocytogenes on the surface of refrigerated, ready-to-eat chicken coated with edible zein film coatings containing nisin and/or calcium propionate. J. Food Sci. 67, 2754-2757, https://doi.org/10.1111/j.1365-2621.2002.tb08810.x

Józefiak D., Kierończyk B., Juśkiewicz J., Zduńczyk Z., Rawski M., Długosz J., Sip A., Højberg O., 2013. Dietary nisin modulates the gastrointestinal microbial ecology and enhances growth performance of the broiler chickens. PloS ONE 8, e85347, https://doi.org/10.1371/journal.pone.0085347

Józefiak D., Sip A., 2013. Bacteriocins in poultry nutrition - a review. Ann. Anim. Sci. 13, 449-462, https://doi.org/10.2478/aoas2013-0031

Józefiak D., Sip A., Rawski M., Steiner T., Rutkowski A., 2011. The dose response effects of liquid and lyophilized Carnobacterium divergens AS7 bacteriocin on the nutrient retention and performance of broiler chickens. J. Anim. Feed Sci. 20, 401-411, https://doi.org/10.22358/jafs/66195/2011

Józefiak D., Sip A., Rutkowski A., Rawski M., Kaczmarek S., WołuńCholewa M., Engberg R.M., Højberg O., 2012. Lyophilized Carnobacterium divergens AS7 bacteriocin preparation improves performance of broiler chickens challenged with Clostridium perfringens. Poultry Sci. 91, 1899-1907, https://doi. org/10.3382/ps.2012-02151

Kierończyk B., Rawski M., Długosz J., Światkiewicz S., Józefiak D., 2016. Avian crop function - a review. Ann. Anim. Sci. 16, 653-678, https://doi.org/10.1515/aoas-2016-0032

Klaver F.A., van der Meer R., 1993. The assumed assimilation of cholesterol by Lactobacilli and Bifidobacterium bifidum is due to their bile salt-deconjugating activity. Appl. Environ. Microb. 59, $1120-1124$
Liffers S.-T., Tilkorn D.J., Stricker I., Junge C.G., Al-Benna S., Vogt M., Verdoodt B., Steinau H.-U., Tannapfel A., Tischoff I., Mirmohammadsadegh A., 2013. Salinomycin increases chemosensitivity to the effects of doxorubicin in soft tissue sarcomas. BMC Cancer 13, 490, https://doi.org/10.1186/1471-2407-13490

Macfarlane G.T., Gibson G.R., 1995. Microbiological aspects of the production of short-chain fatty acids in the large bowel. In: J.H. Cummings, J.L. Rombeau, T. Sakata (Editors). Physiological and Clinical Aspects of Short-Chain Fatty Acids. Cambridge University Press, Cambridge (UK), pp. 87-105

Mansour M., Amri D., Bouttefroy A., Linder M., Milliere J.B., 1999. Inhibition of Bacillus licheniformis spore growth in milk by nisin, monolaurin, and pH combinations. J. Appl. Microbiol. 86, 311-324, https://doi.org/10.1046/j.1365-2672.1999.00669.x

Marteau P., Pochart P., Doré J., Béra-Maillet C., Bernalier A., Corthier G., 2001. Comparative study of bacterial groups within the human cecal and fecal microbiota. Appl. Environ. Microbiol. 67, 4939-4942, https://doi.org/10.1128/AEM.67.10.49394942.2001

Masuda N., 1981. Deconjugation of bile salts by Bacteroides and Clostridium. Microbiol. Immunol. 25, 1-11, https://doi. org/10.1111/j.1348-0421.1981.tb00001.x

Ogita A., Konishi Y., Borjihan B., Fujita K.-i., Tanaka T., 2009. Synergistic fungicidal activities of polymyxin $B$ and ionophores, and their dependence on direct disruptive action of polymyxin $B$ on fungal vacuole. J. Antibiot. 62, 81-87, https://doi.org/10.1038/ ja.2008.13

Riddell C., Kong X.-M., 1992. The influence of diet on necrotic enteritis in broiler chickens. Avian Dis. 36, 499-503, https://doi. org/10.2307/1591740

Sghir A., Gramet G., Suau A., Rochet V., Pochart P., Dore J., 2000. Quantification of bacterial groups within human fecal flora by oligonucleotide probe hybridization. Appl. Environ. Microbiol. 66, 2263-2266, https://doi.org/10.1128/AEM.66.5.22632266.2000

Teo A.Y.-L., Tan H.-M., 2005. Inhibition of Clostridium perfringens by a novel strain of Bacillus subtilis isolated from the gastrointestinal tracts of healthy chickens. Appl. Environ. Microbiol. 71, 4185-4190, https://doi.org/10.1128/AEM.71.8.41854190.2005

Thomas L.V., Davies E.A., Delves-Broughton J., Wimpenny J.W.T., 1998. Synergist effect of sucrose fatty acid esters on nisin inhibition of gram-positive bacteria. J. Appl. Microbiol. 85, 1013-1022, https://doi.org/10.1111/j.1365-2672.1998. tb05266.x

Thomas L., Isak T., 2005. Nisin synergy with natural antioxidant extracts of the herb rosemary. In: Proceedings of the Ist International Symposium on Natural Preservatives in Food Systems. Princeton (USA). Acta Hortic. 709, 109-114

Vescovo M., Orsi C., Scolari G., Torriani S., 1995. Inhibitory effect of selected lactic acid bacteria on microflora associated with ready-to-use vegetables. Lett. Appl. Microbiol. 21, 121-125, https://doi.org/10.1111/j.1472-765X.1995.tb01022.x

Zottola E.A., Yezzi T.L., Ajao D.B., Roberts R.F., 1994. Utilization of cheddar cheese containing nisin as an antimicrobial agent in other foods. Int. J. Food Microbiol. 24, 227-238, https://doi. org/10.1016/0168-1605(94)90121-X 